\title{
Quality criteria, expiration period and marketing loss estimations of pre-treated and cold stored mullet fish
}

\author{
By Ibrahim M. Hassan ", Mohamed F. Khallaf ", Laila E. Abd-El Fattah " and Nessrien M. Yasin \\ Food Sci. Dept., Fac. of Agric., Ain Shams Univ., Cairo, Egypt. \\ Analytical Chem. Dept., Fac. of Pharmacy, Cairo, Egypt.
}

\section{RESUMEN}

Criterios de calidad, estimación del período de vida y pérdidas durante la comercialización del pescado denominado mujol pretratado y conservado en frío.

El trabajo presenta los resultados de la evolución de productos de rotura de proteínas y de la autoxidación de lípidos del pescado mujol criado en cautividad en función de los tratamientos propuestos antes de su enfriamiento a $3^{\circ} \mathrm{C} \pm 1$. Además se sigue la evolución organoléptica durante el almacenamiento en frío de tres tratamientos: pez entero sin vísceras (RM), sin vísceras sumergido en agua destilada (WSRM) y sumergido en una solución conteniendo $5 \%$ sorbato potásico $+5 \% \mathrm{Na}_{4} \mathrm{P}_{2} \mathrm{O}_{7}+2 \%$ citrato sódico $+0,2 \%$ ácido ascórbico (SSRM). Se dedujo el período de almacenamiento en frío así como las pérdidas durante la comercialización de dicho pescado. Asimismo, se estimaron las pérdidas a escala de mayorista y minoristas utilizando formularios.

El nitrógeno básico total (TVB-N) y el nitrógeno como trimetilamina (TMA-N) aumentaron simultáneamente durante el almacenamiento en frío de los mujoles sometidos a los diferentes tratamientos. La oxidación de los lípidos y de los productos de hidrólisis se siguió analizando los índices de peróxido (PV), sustancias que reaccionan con el ácido thiobarbitúrico (TBARS) y relación de absorbancias a 400 y $450 \mathrm{~nm}\left(\mathrm{~A}_{400} / \mathrm{A}_{450}\right)$ así como por la acidez (AV) y los ácidos grasos volátiles libres (FVFA). Estos parámetros mostraron incrementos que dependieron de los tratamientos. Los tratamientos de inmersión retardaron de forma muy importante el proceso de alteración. Como ejemplo, las muestras sometidas a SSRM tardaron en alterarse 15 días mientras que las tratadas con RM y WSRM sólo duraron 8 y 9 días respectivamente.

PALABRAS-CLAVE: Almacenamiento en frío - Calidad - Comercialización - Mujol - Pescado.

\section{SUMMARY}

Quality criteria, expiration period and marketing loss estimations of pre-treated and cold stored mullet fish.

Monitoring of protein breakdown products and lipid autoxidation in farmed mullet fish as a function of a proposed treatments prior to chilling process at $3^{\circ} \mathrm{C} \pm 1$ was carried out. Furthermore, sensory evaluation of three investigated treatments, whole mullet fish (RM)-eviscerated and soaked in distilled water (WSRM)-eviscerated and soaked in a solution containing $5 \% \mathrm{~K}$-sorbate $+5 \% \mathrm{Na}_{4} \mathrm{P}_{2} \mathrm{O}_{7}$ $+2 \% \mathrm{Na}$-citrate $+0.2 \%$ ascorbic acid (SSRM), were followed during chilling storage. Estimation of the predicted length of cold storage period as well as the marketing losses of the marketable mulle fish was also elucidated. The marketing losses of mullet fish at whole or retail market levels were also estimated by using a pre-tested questionnaire.

Total volatile basic nitrogen (TVB-N) and trimethylamine nitrogen (TMA-N) increased concomitantly during cold storage of differently treated mullet fish. Moreover, lipid oxidation and hydrolysis products were followed by determining peroxide value (PV), thiobarbituric acid reactive substances (TBARS) and ratio of absorbance $\left(A_{400} / A_{450}\right)$ as well as acid value $(A V)$ and free volatile fatty acids (FVFA). Mostly, these parameters show upward trend with different rates depending on the applied treatment. Soaking treatment greatly retarded fish spoilage during cold storage. As regards, SSRM samples withstand spoilage up to about 15 days compared to only 8 and 9 days for both RM and WSRM samples, respectively.

KEY-WORDS: Cold storage - Fish - Marketing - Mullet - Quality.

\section{INTRODUCTION}

Fish are becoming increasingly valuable as a good source of protein. It is known to be of great nutritional value for human consumption as its protein has a high biological value and contains all the essential amino acids. Fish is perishable and also is a satisfactory source of vitamins and fats contain essential fatty acids as well as minerals. The higher rate of fish spoilage is mainly due to the high proportion of non-protein nitrogen (NPN) of fish muscle, which their extractives comprise volatile bases, trimethylamine (TMA), TMA-O, urea, creatinin and available amino acids. The spoilage of fish is the result of a whole series of complicated changes brought about in the tissue by its enzymes, bacteria and chemical actions. Krivchenia and Fennema, (1998) noticed that in high fat species, shelf-life is limited by oxidative changes in the lipid and pigments, which cause off-flavours and discoloration of the flesh. Fletcher and Stathan, (1998) showed that the unacceptability was reached rapidly due to autolysis and oxidation for mullet when cold stored at $4{ }^{\circ} \mathrm{C}$ or higher.

There are considerable problems in maintaining fish quality during the period of post-catch handling and distribution. Such problems are (i) the distance of catch from the shore, (ii) the time lapsed before 
the catch is delivered to the consumer, (iii) the high ambient temperature after catch and during the different marketing channels till arrived to the consumer. This time lapse before icing and the exposure to high ambient temperatures encourages the growth of microorganisms resulting in enhanced bacterial count and/or activity. It also induces enzymic spoilage. A reduction of storage temperature by $5-6{ }^{\circ} \mathrm{C}$ will reduce the rate of biochemical reactions to half of its value and may also double the expiration period of fish (Dawood et al., 1986).

Mullet fish is considered one of the main types of fish widely used in the world. In Egypt, it is considered as luxury fish available in the market but with high prices. In this work, monitoring of proteins breakdown and lipid autoxidation in farmed mullet fish as a function of pre-processing treatments (soaking treatments) and chilling process at $3^{\circ} \mathrm{C} \pm 1$ was carried out. The mathematical models for predicting the shelf-life of such products as well as estimation of marketing loss were also suggested.

\section{MATERIAL AND METHODS}

\subsection{Material}

Fresh mullet $(\mathrm{M})$ of the farmed species (Mugil capito) were obtained from El-Zawia fish farm, Kafr El-Sheikh Governorate, Egypt, with the average 250 $\mathrm{g}$ weight each. About $60 \mathrm{~kg}$ fish were selected from three different harvests during December 1996. Just after harvesting, the fish were throughly iced and transferred to the laboratory within 3 to $4 \mathrm{~h}$. Upon arrival, cleaning and washing of fish several times with tap water were applied. Samples were divided immediately into 3 equal groups which were subjected to the following treatments:

Group I: Whole mullet fish kept in a refrigerator at $3^{\circ} \mathrm{C} \pm 1$ (RM).

Group II: Eviscerated (M), washed three times to remove blood, then soaked in water for $1 \mathrm{~min}$, drained for $1 \mathrm{~min}$ and kept in a refrigerator at $3^{\circ} \mathrm{C} \pm 1$ (WSRM).

Group III: Several trials were carried out on different soaking treatments which seemed to be more suitable for extending the shelf-life of mullet fish. The following treatment was found to be the most promising one. Eviscerated (M), soaked for $1 \mathrm{~min}$ in a solution contained $5 \%$ potassium sorbate $+5 \%$ sodium pyrophosphate $+2 \%$ sodium citrate $+0.2 \%$ ascorbic acid, drained for $1 \mathrm{~min}$ and kept in a refrigerator at $3^{\circ} \mathrm{C} \pm 1$ (SSRM).

Three fish samples from each of the previous treatments were packed in a polyethylene bag which subjected to a partial vacuum and heat sealed.

\subsection{Methods}

\subsubsection{Sampling}

The heads, tails, fins and back bones were removed and the remaining flesh was minced twice with an electric "Toshiba" meat mincer. All determinations were done in at least six replicates, each replicate consists of 2 fishes. The mean value as well as the standard error were given. RM samples were drawn for analysis every 2 days, whereas the WSRM and SSRM samples were analysed every 4 days. The three aforementioned products were subjected to chemical and sensory analysis till they were estimated by the panelists to be unaccepted.

\subsubsection{Analytical methods}

The method of Harold et al., (1987) was applied to determine acid value (AV), total volatile basic nitrogen (TVB-N) and thiobarbituric acid reactive substances (TBARS). Meanwhile, the AOAC method, (1990) was used to determine TMA-N, free volatile fatty acids (FVFA) and peroxide value (PV). The browning reaction was followed by measuring the absorbance of lipids at both 400 and $450 \mathrm{~nm}$ $\left(A_{400} / A_{450}\right)$ as described by Hassan, (1980).

\subsubsection{Sensory evaluation}

Fifteen panelists from the staff members of the Food Sci. Dept., Fac. of Agric., Ain Shams Univ. were asked to evaluate the tested products for eye's lustrous, color of gills, odor, texture, appearance and overall quality of fish flesh. A 9-point hedonic scale with 1 designating "dislike very much» and 9 being "like very much" was applied to estimate fish quality. A 9 score represented "extremely desirable characteristics", indicating firm flesh without any mucous on the surface and very desirable odor and appearance. A score of 1 represented "Extremely undesirable" properties, indicating dull, non-elastic flesh with putrid odor. The boarder line of fish acceptability was set at 4.0 , ratings below this score was considered "unacceptable» (Jhaveri et al., 1982).

The average mean values of the aforementioned attributes and their standard error (SE) were calculated. Statistical analysis of the results was done by the analysis of variance. Mathematical formulas and calculations describing the attributes of some selected parameters were also carried out. 


\subsubsection{Prediction model for the estimation of the length of cold storage period:}

Computer statistical analysis was carried out on IBM Computer. Stepwise regression analysis were applied as recommended by Dixon and Brown, (1985) utilizing the EMDP statistical package and exploiting all promising parameters to estimate the length of storage period as well as the degree of correlation between the tested parameters and storage periods.

\subsubsection{Estimation of marketing loss of cold stored mullet fish:}

A simple questionnaire was designed to estimate the marketing loss of mullet fish either during whole or retail marketing. The sample size was 22 questionnaire sheets including different inquiries which was found to be necessary to collect the needed observations. The questionnaire included these informations: name of fishmonger, fish shop size, $n .^{\circ}$ of workers, kind of activity, season of mullet catch, mullet fish types, fish catching places, means of traffic, fish grades ( $n .^{\circ}$ of fishes $/ \mathrm{kg}$ ), time of arrival, preservation technique, length of preservation time, loss rate, expiration periods... etc.

A computer statistical analysis was carried out using both simple and multiple regression analysis as well as simple and multiple correlation. Level of significancy $(P<0.01,0.05,0.1)$ was also tested. The mathematical models were calculated and tested.

\section{RESULTS AND DISCUSSION}

\subsection{Fish protein breakdown during cold storage}

The TVB-N in addition to the TMA-N values are useful indicators to throw the light on fish protein breakdown during cold storage. The initial values of TVB-N in the different three investigated treatments were about 49 to $50 \mathrm{mg}$ TVB-N/100 g dry weight (Table I). With the progression of cold storage a considerable increase in TVB-N for all investigated treatments occurred with different rates depending on the initial treatment. After 4 days of cold storage the rate of TVB-N increase was 5.85, 1.34 and 1.52 $\mathrm{mg}$ TVB-N/100 g/day for RM, WSRM and SSRM samples, respectively. The RM samples showed the highest incremental rate compared to WSRM and SSRM. Similar trend was also noticed all over the storage period. At the end of the storage periods for the RM, WSRM and SSRM treatments, i.e. 10, 11 and 19 days the TVB-N values ranged between 90-100 $\mathrm{mg} / 100 \mathrm{~g}$. However, the TVB-N value of about 100 $\mathrm{mg} / 100 \mathrm{~g}$ indicates incipient spoilage of mullet fish.

The proposed soaking solution was found to be very effective in retarding protein breakdown by delaying and repressing microbial activity especially during the first 4 days of cold storage. Robach and Hickey (1978) and Gelman et al., (1990) pointed out to the inhibitory effect of KS on the growth of most fish spoilers such as Pseudomones spp. The progressive increase in TVB-N during cold storage might be attributed to the breakdown of nitrogenous substances as a result of microbial activity. As the storage time increased the TVB-N value increased concomitantly (El-Dashlouty, 1978 and Ibrahim and El-Zonfuly, 1980).

Table I

Mean values of TVB-N (mg VB/100 g dry weight) and TMA-N $(\mathrm{mg} / 100 \mathrm{~g})$ of differently treated mullet fish stored at $3^{\circ} \mathrm{C} \pm 1$

\begin{tabular}{ccccccc}
\hline \multirow{2}{*}{$\begin{array}{c}\text { Storage } \\
\text { days }\end{array}$} & \multicolumn{3}{c}{ TVB-N } & \multicolumn{2}{c}{ TMA-N } \\
\cline { 2 - 6 } & RM & WSRM & SSRM & RM & WSRM & SSRM \\
\hline Zero & $50.12 \pm 0.00$ & $48.76 \pm 0.00$ & $49.49 \pm 0.00$ & $7.62 \pm 0.12$ & $8.99 \pm 0.37$ & $0.38 \pm 0.05$ \\
4 & $73.50 \pm 0.21$ & $54.11 \pm 0.47$ & $55.58 \pm 0.00$ & $10.53 \pm 0.18$ & $11.73 \pm 0.12$ & $7.70 \pm 0.05$ \\
8 & $93.40 \pm 0.00$ & $83.68 \pm 0.00$ & $80.00 \pm 0.00$ & $13.49 \pm 0.05$ & $12.96 \pm 0.05$ & $8.81 \pm 0.23$ \\
10 & $101.60 \pm 0.00^{* *}$ & & & $14.56 \pm 0.04^{* *}$ & & \\
11 & & $90.29 \pm 0.12^{* *}$ & & & & \\
12 & & & $91.54 \pm 0.00$ & & & $8.07 \pm 0.32^{* *}$ \\
14 & & & $96.26 \pm 0.00$ & & & $9.12 \pm 0.08$ \\
19 & & & $96.31 \pm 0.00^{* *}$ & & & \\
\hline
\end{tabular}

$\pm:$ Standard error (SE).

${ }^{\star \star}$ : At these points, samples were judged organoleptically to be spoiled. 
The level of TMA-N in fresh mullet fish ranged between 6-9 mg TMA-N/100 g (Table I). During subsequent cold storage great differences between treatments were anticipated due to the effect of additional cleaning and washing in WSRM and the antibacterial effect of K-sorbate and Na-pyrophosphate in SSRM. The incremental rates ( $\triangle T M A-N / \Delta$ Time) for the first 4 days storage were about $0.73,0.69$ and $0.33 \mathrm{mg}$ TMA-N/100 g/day for RM, WSRM and SSRM samples, respectively. For the second 4 days such incremental rates were $0.74,0.31$ and $0.28 \mathrm{mg}$ TMA-N/100g/day. Even at the end of cold storage periods the TMA-N values were 14.56, 18.07 and $8.49 \mathrm{mg}$ TMA-N/100 g, respectively. This indicates that the spoilage criterion of both RM and WSRM treatments are mainly due to the off-odor produced upon the rise of TMA-N level whereas SSRM samples are still had low TMA-N level as seen in Table I. This means that the TMA-N concentration in SSRM samples was not responsible for the rejection of these samples by the panelists even after 19 days of cold storage. The explanation of such criteria was given by Shaw et al., (1983) and Bremner and Stathan, (1983). They reported that soaking in K-sorbate inhibited aerobic bacterial growth as well as sorbate being particulary effective in repressing aerobic microorganisms that are responsible for TMA formation which produces fish spoilage odor, on the other hand, sorbate was inhibitor for TMA-O reductase. In addition, the function of K-sorbate as an initial bactericidal followed by its bacteriostatic effect at spoilage state were considered. TMAO is generally present in sea-water fish, moreover, TMA is formed from TMAO by enzymic bacterial reduction during storage (Magnusson and Martinsdottir, 1995). These results are in harmony with Ampola and Keller, (1985); Huss, (1988) and Abo-Taleb, (1993 and 1997). However, Civera et al., (1993) reported that the TVB-N and TMA-N evaluations can not replace the organoleptic examination, but it may help the inspection particularly in fish products.

Data in Table II indicated that there were significant differences $(P<0.01)$ in TVB-N and TMA-N of different treated mullet fish during subsequent cold storage at $3^{\circ} \mathrm{C} \pm 1$. Soaking treatment (SSRM) was found to be a good and effective treatment as far as TVB-N and TMA-N values are concerned. Both RM and WSRM samples showed higher rates of TVB-N and TMA-N increase during cold storage.

\subsection{Lipid deterioration of mullet fish during cold storage}

\subsubsection{Peroxide value (PV)}

At the beginning of storage the peroxide values of differently treated fish were somewhat high (Table III).
This is because of the nature of fish flesh that contained high amount of unsaturated fatty acids which are easily oxidized and produced high amount of peroxides (Fishwick and Swoboda, 1977). A noticeable increase in the rate of peroxides formation was recorded in all investigated treatments throughout their corresponding storage periods. The lowest incremental rate was found in SSRM. This could be attributed to the effectiveness of antioxidant properties of both sodium citrate/ascorbic acid treatment, in retarding lipid oxidation, in addition to the role of KS, which could also be considered as an effective antioxidant treatment in fatty fish (Shenouda et al., 1979). On the other hand, pyrophosphate has antioxidant properties by chelating any metal ions, particularly ferrous iron ions, which are the major prooxidants in meat systemis (Love and Pearson, 1974). The PV was fallen down only in SSRM treatment which withstand spoilage up to 19 days. This is because the rate of peroxides degradation is more than the rate of its formation (Hassan, 1980).

Table II

Analysis of variance for TVB-N and TMA-N of differently treated mullet fish during storage at $3^{\circ} \mathrm{C} \pm 1 / 8$ days

\begin{tabular}{lcccc}
\hline \multirow{2}{*}{ Source of variance } & D.F. & Tabulated F value & \multicolumn{2}{c}{ F-Calculated and level of significancy } \\
\cline { 4 - 5 } & & & TVB-N & TMA-N \\
\hline Time & 2 & 3.26 & $20335.51^{* *}$ & $429.00^{* *}$ \\
Treatment & 2 & 3.26 & $4644.42^{* *}$ & $371.10^{* *}$ \\
Time $\times$ Treatment & 4 & 2.63 & $7408.05^{* *}$ & $27.16^{* *}$ \\
Error & 36 & - & - & - \\
Total & 44 & - & - & - \\
\hline
\end{tabular}

D.F.: Degree of freedom.

**: Significant at $1 \%$ level.

\subsubsection{Thiobarbituric acid reactive substances (TBARS)}

The highest TBA value that colorimetrically measured for SSRM treatment at zero time storage (Table III) may be due to, the interference of soaking compounds in the development of red color reaction between malonaldehyde and 2-TBA and/or to the effect of ascorbic acid which could acts as a prooxidant at a certain concentration (Deng et al., 1978). On the other hand, many substances such as heme iron, tocopherol, citric acid, amino acids, etc., that usually present in muscle tissue may influence the shift of ascorbic acid from antioxidant to prooxidant (Watts and Wong, 1951). The possible 
cause of ascorbic acid acting as a prooxidant is due to the regeneration of reduced metal iron, which is more active than oxidized metal ion (Smith and Dunkley 1962). However, SSRM treatment showed the lowest incremental pattern during cold storage than that of the other two treatments. It is of interest to notice that the maximum TBA value for RM treatment was recorded after 8 days storage, being 0.72 , but it showed 0.27 after 10 days storage (organoleptically rejected), this reflects the instability and reactivity of oxidation products in muscle foods. For example, malonaldehyde produced as a result of lipid oxidation, might react irreversibly with other components, particularly amino acids, proteins and non enzymatic browning intermediates in a Maillard-like reaction (Zirlin and Karel, 1969). The obtained results are in agreement with that of Hassan, (1980), Khallaf, (1982) and Abo-Taleb, (1993 and 1997).

\subsubsection{Free volatile fatty acids (FVFA)}

Volatile fatty acids were formed during lipolysis of fats and further oxidation of lipid peroxides as well as carbonyl compounds. Branen, (1979) discussed the potential for interaction of lipid oxidation and microbial spoilage with reference to the possibility of liberation of free fatty acids by microbial action.

During subsequent cold storage at $3{ }^{\circ} \mathrm{C} \pm 1$, a progressive rise in the conc. of FVFA were taken place for all investigated treatments. The highest rate of increase was found in RM samples, whereas the lowest rate was observed in SSRM samples (Table III). The low incremental rate of FVFA in soaked samples may be due to the dual effect of soaking solution on retarding both autoxidation and microbial activity. Furthermore, soaking solution has alkaline properties which may neutralize the liberated FVFA.

Table III

Effect of cold storage on lipid hydrolysis and oxidation measurements of differently treated mullet fish

\begin{tabular}{|c|c|c|c|c|c|c|c|c|}
\hline \multirow{2}{*}{ Treatments } & \multicolumn{8}{|c|}{ Storage days } \\
\hline & Zero & 4 & 8 & 10 & 11 & 12 & 14 & 19 \\
\hline & \multicolumn{8}{|c|}{ Peroxide value ${ }^{(a)}$} \\
\hline $\mathrm{RM}$ & $4.56 \pm 0.06$ & $15.66 \pm 0.10$ & $29.50 \pm 0.04$ & $34.70 \pm 0.09^{\star \star}$ & & & & \\
\hline WSRM & $4.19 \pm 0.01$ & $19.56 \pm 0.12$ & $29.67 \pm 0.09$ & & $38.49 \pm 0.008^{\star \star}$ & & & \\
\hline \multirow[t]{2}{*}{ SSRM } & $4.75 \pm 0.06$ & $12.54 \pm 0.04$ & $22.14 \pm 0.04$ & & & $21.57 \pm 0.13$ & $40.14 \pm 0.04$ & $35.87 \pm 0.09^{* \star}$ \\
\hline & \multicolumn{8}{|c|}{$\mathrm{TBA}^{\text {(b) }}$} \\
\hline RM & $0.07 \pm 0.00$ & $0.27 \pm 0.00$ & $0.72 \pm 0.03$ & $0.27 \pm 0.02^{* *}$ & & & & \\
\hline WSRM & $0.13 \pm 0.00$ & $0.11 \pm 0.00$ & $0.36 \pm 0.01$ & & $0.85 \pm 0.00^{\star \star}$ & & & \\
\hline \multirow[t]{2}{*}{ SSRM } & $0.23 \pm 0.00$ & $0.30 \pm 0.00$ & $0.34 \pm 0.01$ & & & $0.41 \pm 0.01$ & $0.56 \pm 0.00$ & $0.61 \pm 0.01^{\star \star}$ \\
\hline & \multicolumn{8}{|c|}{ Free volatile fatty acids * } \\
\hline $\mathrm{RM}$ & $3.98 \pm 0.00$ & $48.95 \pm 0.00$ & $58.60 \pm 0.40$ & $77.4 \pm 0.8^{\star *}$ & & & & \\
\hline WSRM & $7.60 \pm 0.09$ & $27.20 \pm 0.35$ & $38.68 \pm 0.00$ & & $51.32 \pm 0.42^{\star \star}$ & & & \\
\hline \multirow[t]{2}{*}{ SSRM } & $3.90 \pm 0.00$ & $20.14 \pm 0.27$ & $36.70 \pm 0.00$ & & & $42.3 \pm 0.00$ & $45.5 \pm 0.00$ & $48.1 \pm 0.40^{* *}$ \\
\hline & \multicolumn{8}{|c|}{$A_{400} / A_{450}$} \\
\hline $\mathrm{RM}$ & $1.44 \pm 0.00$ & $1.21 \pm 0.01$ & $1.07 \pm 0.01$ & $1.36 \pm 0.01^{\star *}$ & & & & \\
\hline WSRM & $0.94 \pm 0.01$ & $1.44 \pm 0.01$ & $1.30 \pm 0.00$ & & $1.13 \pm 0.00^{\star \star}$ & & & \\
\hline \multirow[t]{2}{*}{ SSRM } & $0.82 \pm 0.00$ & $0.80 \pm 0.00$ & $0.77 \pm 0.00$ & & & $0.82 \pm 0.00$ & $0.61 \pm 0.00$ & $0.4 \pm 0.00^{* *}$ \\
\hline & \multicolumn{8}{|c|}{ Acid value *** } \\
\hline $\mathrm{RM}$ & $1.37 \pm 0.02$ & $5.47 \pm 0.06$ & $7.40 \pm 0.06$ & $7.70 \pm 0.15^{\star \star}$ & & & & \\
\hline WSRM & $1.29 \pm 0.01$ & $5.15 \pm 0.05$ & $7.06 \pm 0.02$ & & $7.88 \pm 0.08^{* \star}$ & & & \\
\hline SSRM & $1.42 \pm 0.02$ & $3.70 \pm 0.04$ & $3.88 \pm 0.02$ & & & $4.20 \pm 0.09$ & $5.76 \pm 0.04$ & $8.24 \pm 0.06^{* *}$ \\
\hline
\end{tabular}

*: $\quad$ as $\mathrm{ml} \mathrm{NaOH} 0.1 / 100 \mathrm{~g}$ dry weight.

***: as $\mathrm{mg}$ alcohol $\mathrm{KOH} / \mathrm{g}$ lipid.

\pm : Standard error (SE).

**: At these points, samples were judged organoleptically to be spoiled.

(a): as meq/Kg. lipid.

(b): as O.D. at $538 \mathrm{~nm}$. 


\subsubsection{Ratio of absorbance (A400/A450)}

The browning reaction was followed by measuring the absorbance of extracted lipids at both 400 and 450nm (Pokorny et al., 1974 and 1975). Table III shows the rate of the browning reaction in different treated mullet fish which was generally slow during cold storage at $3{ }^{\circ} \mathrm{C} \pm 1$. The ratio $\mathrm{A}_{400} / \mathrm{A}_{450}$ was decremental by time indicating more formation of the brown pigments over the yellow ones. The higher rate of decrease was found in RM. These findings agree with those observed by Hassan, (1980).

\subsubsection{Acid value (AV)}

Hydrolytic reactions of lipids occurred during cold storage of fish. These reactions may be related to the activity of natural lipo-protein lipases present in the tissue of fish and also to the species of bacteria present in the product which can utilize fats and intermediate fatty compounds as a source of carbon (Halliday, 1972).

Progressive rise in AV was noticed during cold storage (Table III). The low rate of increase of AV in SSRM samples compared to both RM and WSRM (Table III) could be attributed to the effectiveness of soaking treatments which reduced the rate of lipid oxidation and hydrolysis. This was obvious all over the storage period where the acid value of SSRM samples was always less than that of both RM and WSRM samples.

The analysis of variance (Table IV) for lipid deterioration parameters of differently treated mullet fish stored at $3^{\circ} \mathrm{C} \pm 1$ proved that there were significant differences $(P<0.01)$ in PV, TBA, FVFA, $A_{400} / A_{450}$ and $A V$ values during cold storage. This indicates that all lipid deterioration parameters selected to follow changes in fish quality and estimating their expiration periods were efficient and promising.

Table IV

Analysis of variance for some lipid deterioration parameters of differently treated mullet fish during storage at $3^{\circ} \mathrm{C} \pm 1 / 8$ days

\begin{tabular}{|c|c|c|c|c|c|c|c|}
\hline \multirow{2}{*}{ Source of variance } & \multirow{2}{*}{ D.F. } & \multirow{2}{*}{$\begin{array}{l}\text { Tabulated } \\
\text { F value }\end{array}$} & \multicolumn{5}{|c|}{ F-Calculated and level of significancy } \\
\hline & & & PV & TBA & FVFA & $A_{400} / A_{450}$ & AV \\
\hline Time & 2 & 3.26 & $76482.58^{\star \star}$ & $648.15^{\star \star}$ & $27158.35^{\star \star}$ & $245.24^{\star \star}$ & $11667.69^{* \star}$ \\
\hline Treatment & 2 & 3.26 & $3497.25^{\star \star}$ & $125.68^{\star \star}$ & $843.85^{\star \star}$ & $4482.75^{\star \star}$ & $173.63^{\star \star}$ \\
\hline Time $\mathrm{x}$ Treatment & 4 & 2.63 & $1334.44^{\star \star}$ & $171.75^{\star \star}$ & $1551.08^{\star \star}$ & $1076.98^{\star \star}$ & $645.06^{\star \star}$ \\
\hline Error & 36 & - & - & - & - & - & - \\
\hline Total & 44 & - & - & - & - & - & - \\
\hline
\end{tabular}

D.F.: Degree of freedom.

**: Significant at $1 \%$ level.

\subsection{Sensory properties}

In the present investigation, the panelists were asked to evaluate the eye's lustrous, color of gills, odor, texture, appearance and the overall quality of differently treated mullet fish. In conclusion, by examining all the obtained data of differently treated mullet fish, we could safely estimate the expiration periods of the three mullet fish samples (Stored at $3{ }^{\circ} \mathrm{C} \pm 1$ ) to be as follows:

RM samples: about 8 days.

WSRM samples: about 9 days.

SSRM samples: about 15 days.

According to these estimates, fish evisceration with additional washing (WSRM) could extend the shelf-life of mullet fish 1 day more, whereas, when eviscerated fish was soaked as was proposed $\left(\mathrm{Na}_{4} \mathrm{P}_{2} \mathrm{O}_{7}+\mathrm{K}\right.$-sorbate $+\mathrm{Na}$ citrate + ascorbic acid $)$ the expiration period of this treatment could be prolonged to be about 15 days (Table V).

\subsection{Prediction model for the estimation of the length of cold storage period}

In accordance with the objective of this study, multiple regression equations (utilized all promising parameters shown in Table $\mathrm{VI}$ as independent variables) were exploited to estimate the length of cold storage period. Regression equations were computed in a stepwise manner according to the procedure that would give maximum coefficient of multiple determination $\left(R^{2}\right)$. At each step, the variable that was added to the equation was the one which would give the greatest reduction in error sum of squares or, equivalently the variable which had the largest partial correlation with the dependent variable (length of cold storage), among those variables not yet included. 
Table V

Sensory attributes of differently treated mullet fish during cold storage at $3^{\circ} \mathrm{C}$

\begin{tabular}{|c|c|c|c|c|c|c|c|c|}
\hline \multirow{2}{*}{ Treatments } & \multicolumn{8}{|c|}{ Storage days } \\
\hline & Zero & 4 & 8 & 10 & 11 & 12 & 14 & 19 \\
\hline & \multicolumn{8}{|c|}{ Eye's lustrous } \\
\hline $\mathrm{RM}$ & $9.0 \pm 0.00$ & $6.9 \pm 0.18$ & $4.5 \pm 0.17$ & $2.5 \pm 0 . .^{\cdots *}$ & & & & \\
\hline WSRM & $9.0 \pm 0.00$ & $6.8 \pm 0.20$ & $5.2 \pm 0.25$ & & $*$ & & & \\
\hline \multirow[t]{2}{*}{ SSRM } & $8.8 \pm 0.13$ & $7.5 \pm 0.17$ & $6.3 \pm 0.15$ & & & $5.2 \pm 0.13$ & $4.3 \pm 0.15$ & $1.9 \pm 0.23^{\star \star}$ \\
\hline & \multicolumn{8}{|c|}{ Color of gills } \\
\hline $\mathrm{RM}$ & $8.5 \pm 0.17$ & $6.7 \pm 0.15$ & $3.7 \pm 0.15$ & $1.0 \pm 0.00^{* *}$ & & & & \\
\hline WSRM & $8.7 \pm 0.15$ & $6.3 \pm 0.15$ & $5.1 \pm 0.23$ & & $1.6 \pm 0.16^{* *}$ & & & \\
\hline \multirow[t]{2}{*}{ SSRM } & $8.8 \pm 0.13$ & $7.7 \pm 0.15$ & $6.5 \pm 0.17$ & & & $5.9 \pm 0.10$ & $4.7 \pm 0.15$ & $3.9 \pm 0.23^{* *}$ \\
\hline & \multicolumn{8}{|c|}{ Odor } \\
\hline $\mathrm{RM}$ & $9.0 \pm 0.00$ & $7.1 \pm 0.18$ & $4.5 \pm 0.22$ & $1.0 \pm 0.00^{* *}$ & & & & \\
\hline WSRM & $9.0 \pm 0.00$ & $6.6 \pm 0.22$ & $4.6 \pm 0.16$ & & $1.0 \pm 0.00^{* *}$ & & & \\
\hline \multirow[t]{2}{*}{ SSRM } & $9.0 \pm 0.00$ & $7.5 \pm 0.17$ & $5.7 \pm 0.15$ & & & $6.8 \pm 0.25$ & $5.4 \pm 0.16$ & $1.0 \pm 0.00^{\star *}$ \\
\hline & \multicolumn{8}{|c|}{ Texture } \\
\hline $\mathrm{RM}$ & $9.0 \pm 0.00$ & $7.4 \pm 0.16$ & $4.5 \pm 0.17$ & $1.0 \pm 0.00^{\star *}$ & & & & \\
\hline WSRM & $9.0 \pm 0.00$ & $6.8 \pm 0.20$ & $4.8 \pm 0.25$ & & $1.0 \pm 0.00^{* *}$ & & & \\
\hline \multirow[t]{2}{*}{ SSRM } & $9.0 \pm 0.00$ & $7.5 \pm 0.17$ & $6.4 \pm 0.16$ & & & $6.3 \pm 0.15$ & $5.6 \pm 0.16$ & $1.0 \pm 0.00^{\star \star}$ \\
\hline & \multicolumn{8}{|c|}{ Appearance } \\
\hline $\mathrm{RM}$ & $9.0 \pm 0.00$ & $7.5 \pm 0.17$ & $4.6 \pm 0.16$ & $1.0 \pm 0.00^{* *}$ & & & & \\
\hline WSRM & $9.0 \pm 0.00$ & $6.8 \pm 0.25$ & $5.5 \pm 0.22$ & & $1.0 \pm 0.00^{\star *}$ & & & \\
\hline \multirow[t]{2}{*}{ SSRM } & $9.0 \pm 0.00$ & $7.7 \pm 0.15$ & $6.4 \pm 0.16$ & & & $6.6 \pm 0.16$ & $4.3 \pm 0.15$ & $1.2 \pm 0.13^{\star \star}$ \\
\hline & \multicolumn{8}{|c|}{ Overall acceptability } \\
\hline $\mathrm{RM}$ & $8.8 \pm 0.13$ & $7.3 \pm 0.21$ & $4.2 \pm 0.20$ & $1.0 \pm 0.00^{* *}$ & & & & \\
\hline WSRM & $9.0 \pm 0.00$ & $6.7 \pm 0.30$ & $4.5 \pm 0.17$ & & $1.0 \pm 0.00^{\star \star}$ & & & \\
\hline SSRM & $9.0 \pm 0.00$ & $7.5 \pm 0.17$ & $6.5 \pm 0.17$ & & & $6.4 \pm 0.16$ & $4.6 \pm 0.16$ & $1.0 \pm 0.00^{* \star}$ \\
\hline
\end{tabular}

\pm : Standard error (SE).

${ }_{\star \star *}^{ \pm} \quad$ At these points, samples were judged organoleptically to be spoiled.

Regression equations for predicting length of cold storage period are presented. On the other hand, the value of the independent variable could be expected at any certain time of cold storage. The independent variable which have had the highest partial correlation with the length of cold storage is the $A_{400} / A_{450}$. The partial correlation between $A_{400} / A_{450}$ and the dependent variable was as much as 0.73 . As shown also from the 1st multiple regression equation the standard error was relatively low (0.86). Therefore, the incorporation of combinations of other chemical parameters into the regression equations, resulted in significant increase in $R^{2}$ with a corresponding reduction in the standard error. When the total volatile basic nitrogen was introduced in the 2 nd step the partial correlation between the length of cold storage and the two independent variables
$\left(A_{400} / A_{450}\right.$ and TVB-N) became greater and increased from 0.73 to 0.81 . In the same manner, FVFA, AV, PV and TBA were contributed significantly to the equations for estimating the length of cold storage period.

The six equations (Table VI) would accurately estimate the length of cold storage period of differently treated mullet fish. Testing of the previous six equations using the available data $\left(A_{400} / A_{450}\right.$, TVB-N, FVFA, AV, PV and TBA) have resulted in the anticipation of cold storage periods of differently treated mullet fish. However, when three independent vari Dis:s (TVB-N, FVFA and $A_{400} / A_{450}$ ) were only introduced in the prediction equation and testing of this equation was carried out, the calculated values were 10.0, 9.7 and 17.6 days for real values 10,11 and 19 days, respectively. 
It seems likely that the scope of estimating the length of cold storage periods was increased as a result of increasing the number of tested parameters, but time consuming and cost of analysis, limit or exclude such trend. The first four parameters TVB-N, FVFA, $A_{400} / A_{450}$ and $A V$ are practically and theoritically
$\left(R^{2}: 0.89\right)$ sufficient to estimate the probable length of cold storage period of differently treated mullet fish. It should be also mentioned that any parameters added at a certain equation is the one which have provided the highest partial correlation with the length of cold storage and improves the accuracy of estimation.

Table VI

Step-wise multiple regression of differently treated mullet fish stored at $3^{\circ} \mathrm{C} \pm 1$

\begin{tabular}{|c|c|c|c|c|c|c|c|c|c|}
\hline Step & Independent variables & $\begin{array}{l}\text { Intercept } \\
\text { (a) }\end{array}$ & $\begin{array}{l}\text { Regression } \\
\text { coefficient } \\
\text { (b) }\end{array}$ & $\begin{array}{l}\text { Standard } \\
\text { error }\end{array}$ & $y=a+b_{1} x_{1}+b_{2} x_{2}+\ldots$ etc. & $R^{2} \%$ & $\begin{array}{l}\text { Residual } \\
\text { standard } \\
\text { deviation }\end{array}$ & $\begin{array}{l}\text { Calculated } \\
\text { values/day }\end{array}$ & $\begin{array}{c}\text { Real } \\
\text { values/day }\end{array}$ \\
\hline \multirow[t]{3}{*}{1} & $\mathrm{~A}_{400} / \mathrm{A}_{450}$ & 25.81 & -11.57 & 0.86 & $y=25.81-11.57 x_{1}$ & 0.73 & 2.23 & 10.1 & 10 \\
\hline & & & & & & & & 10.8 & 11 \\
\hline & & & & & & & & 18.7 & 19 \\
\hline \multirow[t]{3}{*}{2} & Total volatile basic- $\mathrm{N}$ & 32.49 & -0.07 & 0.01 & $y=32.49-0.07 x_{1}-12.76 x_{2}$ & 0.81 & 1.88 & 10.6 & 10 \\
\hline & $A_{400} / A_{450}$ & & -12.76 & 0.75 & & & & 11.8 & 11 \\
\hline & & & & & & & & 18.2 & 19 \\
\hline \multirow[t]{3}{*}{3} & Total volatile basic- $\mathrm{N}$ & 37.2 & -0.15 & 0.02 & $y=37.2-0.15 x_{1}+0.08 x_{2}-13.88 x_{3}$ & 0.86 & 1.64 & 10.0 & 10 \\
\hline & Free volatile fatty acids & & 0.08 & 0.02 & & & & 9.7 & 11 \\
\hline & $A_{400} / A_{450}$ & & -13.88 & 0.69 & & & & 17.6 & 19 \\
\hline \multirow[t]{4}{*}{4} & Total volatile basic- $\mathrm{N}$ & 38.16 & -0.15 & 0.02 & $y=38.16-0.15 x_{1}+0.14 x_{2}-13.74 x_{3}$ & 0.89 & 1.46 & 10.6 & 10 \\
\hline & Free volatile fatty acids & & 0.14 & 0.02 & & & & 11.5 & 11 \\
\hline & $\mathrm{A}_{400} / \mathrm{A}_{450}$ & & -13.74 & 0.62 & & & & 20.0 & 19 \\
\hline & Acid value & & -0.60 & 0.14 & & & & & \\
\hline \multirow[t]{5}{*}{5} & Total volatile basic- $\mathrm{N}$ & 37.75 & -0.16 & 0.02 & $y=37.75-0.16 x_{1}+0.11 x_{2}-12.94 x_{3}$ & 0.91 & 1.36 & 9.2 & 10 \\
\hline & Free volatile fatty acids & & 0.11 & 0.02 & & & & 11.4 & 11 \\
\hline & $A_{400} / A_{450}$ & & -12.94 & 0.63 & & & & 18.8 & 19 \\
\hline & Peroxide value & & 0.13 & 0.04 & & & & & \\
\hline & Acid value & & -1.00 & 0.18 & & & & & \\
\hline \multirow[t]{6}{*}{6} & Thiobarbituric acid & 38.57 & -3.99 & 1.17 & $y=38.57-3.99 x_{1}-0.15 x_{2}+0.11 x_{3}$ & 0.92 & 1.26 & 9.9 & 10 \\
\hline & Total volatile basic- $\mathrm{N}$ & & -0.15 & 0.02 & 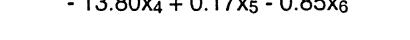 & & & 10.0 & 11 \\
\hline & Free volatile fatty acids & & 0.11 & 0.02 & & & & 18.9 & 19 \\
\hline & $\mathrm{A}_{400} / \mathrm{A}_{450}$ & & -13.80 & 0.63 & & & & & \\
\hline & Peroxide value & & 0.17 & 0.04 & & & & & \\
\hline & Acid value & & -0.85 & 0.17 & & & & & \\
\hline
\end{tabular}

From the above mentioned equations, it may be concluded that stepwise regression analysis was successfully used to assess regression equations for storage period estimation. However, storage length prediction could be achieved in cold stored and differently pre-treated mullet fish by determining the mentioned parameters.

\subsection{Estimation of marketing losses of cold stored mullet fish}

The marketing losses of mullet fish either at whole or retail market levels were estimated by using a previously tested questionnaire. Analysis of the collected data were carried out by utilizing both simple and multiple regression analysis as well as both simple and multiple correlations. Significancy of the obtained results were also tested. The results have proved the following:

5.1. - Mullet fish loss during storage at the fish shop was not significantly affected by either $n .{ }^{\circ}$ of workers working in the fish shop or preservation techniques as all fishmongers used only crushed ice preservation.

5.2.- No significant changes have been taken place due to the method of fish sale either by auction sale or payment after sale.

5.3.- Fish loss is greatly affected by the dependent variable $X_{3}$ which resembles the degree 
of fish quality ( $\mathrm{r}^{\circ}$ of fishes $/ \mathrm{Kg}$ ). It proved that as the degree of fish quality increased (less $\mathrm{n} .^{\circ}$ of fishes $/ \mathrm{Kg}$ ) the rate of fish loss decreased (Equation 3 - Table VII). As the fish quality decreased by only one grade the rate of fish loss increased by $1.47 \%$. This variable explains about $14 \%$ of the loss occurred during whole or retail marketing of mullet fish.

5.4.- Positive regression relationship was found between the fish shop size and the rate of fish loss $(P<0.1)$. From equation 1 it was found that as the fish shop size increased by $1 \mathrm{~m}$. the rate of fish loss decreased by $3.8 \%(P<0.1)$, moreover, shop size as a dependent variable explains about $12 \%$ of the factors responsible for fish losses.

5.5.- It is well known that the length of cold storage in the fish shop had a significant effect on the amount of fish loss (Eq. 4). During the 1st two storage days, as the storage time $\left(X_{5}\right)$ increased $10 \mathrm{hr}$ intervals the rates of fish losses increased by about $6 \%(P<0.1)$, this dependent variable $\left(X_{5}\right)$ explains about $9 \%$ of fish losses (Eq. 4).

5.6. - It is also known that (Eq. 6) as the time after catch extended, the fish loss rate increased. Similarly, each $10 \mathrm{hr}$ intervals after catch lead to $6 \%$ fish loss $(P<0.1)$.

5.7.- Regression equations were computed in a stepwise manner according to the procedure that would give maximum coefficient of multiple determination $\left(R^{2}\right)$.

By exploiting all promising parameters the best model was found to be illustrated in equation $n .^{\circ} 8$ as follows:

$$
\begin{gathered}
y=0.36-0.04 X_{1}+0.59 X_{3}+0.04 X_{5} \\
(1.35) \quad(0.43) \quad(0.59)
\end{gathered}
$$

These three dependent variables $\left(X_{1}, X_{3}, X_{5}\right)$ explain about $22 \%$ from the amount of mullet fish loss during retail or whole marketing. The remaining loss $(78 \%)$ may be due to other variables which were not shown in questionnaire sheet, or to the low $n .^{\circ}$ of observation and/or to less relative truth from the fishmongers during data collection.

In conclusion, fish losses during marketing is of great importance in which the food scientists always try to do their best efforts to reduce such loss. From the observations illustrated in the questionnaire the expiration period of mullet fish as estimated by fishmongers was about 4 days.
Table VII

Suggested mathematical model describing the estimated fish losses during whole

\begin{tabular}{|c|c|c|c|}
\hline N. ${ }^{\circ}$ & Calculated losses & $R^{2}$ & $F$ \\
\hline 1 & $y=2.627 \cdot 0.038 x_{1}$ & 0.12 & 2.56 \\
\hline 2 & $y=2.47+0.22 X_{2}$ & 0.07 & 1.35 \\
\hline 3 & $y=1.14+1.47 x_{3}$ & 0.14 & 2.30 \\
\hline 4 & $y=1.43+0.06 X_{5}$ & 0.09 & 1.85 \\
\hline 5 & $y=2.50+1.13 X_{6}$ & 0.02 & 0.31 \\
\hline 6 & $y=1.43+0.06 X_{7}$ & 0.09 & 1.85 \\
\hline 7 & $y=0.86-0.03 X_{1}+1.2 X_{3}$ & 0.21 & 2.33 \\
\hline 8 & $y=0.36-0.04 X_{1}+0.59 X_{3}+0.04 X_{5}$ & 0.22 & 1.61 \\
\hline $\begin{array}{l}y: \text { Mark } \\
X_{2}: N .^{\circ} \\
X_{5}: \text { Len } \\
X_{7}: \text { Len }\end{array}$ & \multicolumn{3}{|c|}{$\begin{array}{l}\mathrm{X}_{\mathrm{1}} \text { : Shop size. } \\
\mathrm{X}_{\mathrm{S}} \text { : Quality grades ( } \mathrm{N} .{ }^{\circ} \text { of mullet fishes } / \mathrm{Kg} \text {.) } \\
\mathrm{X}_{\mathrm{S}}: \text { Type of marketing. } \\
(\mathrm{)} \text { : Values between brackets are calculated "T" }\end{array}$} \\
\hline
\end{tabular}
and retail marketing

\section{REFERENCES}

Abo-Taleb, M. (1993).-_Effect of some processing treatments on the chemical compounds of some fish varieties".-M. Sc. Thesis, Fac. of Agric., Ain Shams Univ., Cairo, Egypt.

Abo-Tableb, M. (1997).- «Studies on the utilization of carp fish in some fishery products".-Ph. D. Thesis, Fac. of Agric., Ain Shams Univ., Cairo, Egypt.

Ampola, G.V. and C.L. Keller (1985).- «Shelf-life extension of drawn whole Atlantic cod, Gadus morhua and cod fillets by treatment with potassium sorbate».-Marine Fisheries Review. National Oceanic and Atmospheric Administration. 47(3) 26-29.

A.O.A.C. (1990).- «Official Methods of Analysis».Association of Official Analytical Chemists. Washington, D.C.

Branen, A.L. (1979). - «Interaction of fat oxidation and microbial spoilage in muscle foods".-Food Science and Technology, 156.

Bremner, H.A. and J.A. Stathan (1983).- - «Effect of potassium sorbate on refrigerated storage of vacuum packed scallops".-J. Food Sci., 48: 1042.

Civera, T.; R.M. Turi; C. Bisio; E. Parisi and G. Fazio (1993).- - «ensory and chemical assessment of marine teleosteans".-Sciences Des Aliments, 13: 109.

Dawood, A.A.; R.N. Roy and C.S. Williams (1986)."Quality of rainbow trout chilled-stored after post-catch holding".-J. Sci. Food Agric., 37: 421.

Deng, J.C.; M. Watson; R.P. Bates and E. Schroeder (1978). - «Ascorbic acid as an antioxidant in fish flesh and its degradation".-J. Food Sci., 43: 457.

Dixon, W.J. and M.B. Brown (1985).-—Stepwise Regression Procedure».-Richard D. Irwin Inc. Hamwood Illinoois 60430, p. 430.

El-Dashlouty, A.A. (1978).- «Studies on the quality of some meat products".-Ph. D. Thesis, Fac. of Agric., Ain Shams Univ., Cairo, Egypt. 
Fishwick, M.J. and P.A.T. Swoboda (1977).- «Measurement of oxidation of polyunsaturated fatty acids by spectrophotometric assay of conjugated derivatives".J. Sci. Food. Agric., 28: 387.

Fletcher, G.C. and J.A. Stathan (1988).- «Deterioration of sterile chill -stored and frozen trumpeter fish (Latridopsis forsteri)".-J. Food Sci., 53: 1336.

Gelman, A.; R. Pasteur and M. Rave (1990).- «Quality changes and storage life of common carp (Cyprinus carpio) at various storage temperatures".-J. Sci., Food Agric., 52: 231.

Halliday, D.A. (1972). - «Sausage meat changes in cold storage".-Process Biochemistry, 7: 18.

Harold, E.; S.K. Ronald and S. Roland (1987)._-«Pearson's chemical analysis of foods". -8 th Ed. Longman House, Burnt, M.; Harbow, Essex CM 202 JE, England.

Hassan, I.M. (1980).— - The effect of irradiation treatments alone or accompanied with other treatments on some properties of meat".-Ph. D. Thesis, Fac. of Agric., Ain Shams Univ., Cairo, Egypt.

Huss, H.H. (1988). - «Fresh fish quality and quality changes".-FAO Fisheries Series, 29, Rome.

Ibrahim, A.A. and H.T., El-Zonfuly (1980). - -Boulti (Tilapia nilotica) fish paste. I. Preparation and chemical composition".-Z. Emahrung-wiss, 19: 601.

Jhaveri, S.N.; S.S. Leu and S.M. Constantinides (1982)."Atlantic mackerel (Scomber scomberus L.): shelf-life in ice».-J. Food Sci., 47: 1808.

Khallaf, M.F. (1982).- "Studies on the irradiation of fish".-M. Sc. Thesis, Fac. of Agric., Ain Shams Univ., Cairo, Egypt.

Krivchenia, M. and O. Fennema (1988).-— «Effect of cryoprotectants on frozen whitefish fillets".-J. Food Sci., 53: 999.
Love, J.D. and A.M. Pearson (1974)._- Metmyoglobin and non-heme irons as prooxidants in cooked meat".- J. Agric. Food. Chem., 22: 1032.

Magnusson, H. and E. Martinsdottir (1995).- «Storage quality of fresh and frozen-thawed fish in ice".-J. Food Sci., 60: 273

Pokorny, J.; A. Kolakowaska; B.A. El-Zeany and G. Janicek (1975). - «Z. Lebensm. Unters».-Forsch. 157: 323.

Pokorny, J.; B.A. El-Zeany; A. Kolakowaska and J. Janicek (1974).— «Z. Lebensm. Unters».-Forsch. 155: 287.

Robach, M.C. and C.S. Hickey (1978)._- Inhibition of Vibrio parahaemolyticus by sorbic acid in crab meat and flounder homogenates". - J. Food Protection, 41: 699.

Shaw, S.L.; E.G. Bligh and A.D. Woyewoda (1983).«Effect of potassium sorbate application on shelf life of Atlantic cod (Gadus morhua)». - Can. Inst. Food Sci. Technol. J., 16: 237.

Shenouda, S.Y.K.: JR.V.M. Joseph; S. Jhaveri and S.M. Constantinides (1979).— «Technological studies on ocean pout, an unexploited fish species for direct human consumption».-J. Food Sci., 44: 164.

Smith, G.L. and W.L. Dunkley (1962).- «Initial of lipid peroxidation reduced metal ion".-Arch. Biochem. Biophys., 98: 46.

Watts, B.M. and R. Wong (1951).- «Some factors affecting the antioxidant behavior of ascorbic acid with unsaturated fats".-Arch. Biochem., 24: 110.

Zirlin, A. and M. Karel (1969)._- Oxidation effects in a freeze dried gelatin methyl linoleate system».-J. Food Sci., 34: 160. 